\title{
Evaluation of Thirty Amaranthus Genotypes (Amaranthus tricolor L.) for Different Biometric Characters
}

\author{
A. M. Shahiba*, Beena Thomas and Arun Chacko \\ College of Agriculture (KAU), Vellayani, Trivandrum- 695 522, Kerala, India \\ *Corresponding author
}

Keywords

Amaranthus tricolor

L., Genotypes,

Germplasm,

Variability,

Characters, Yield

Article Info

Accepted:

15 July 2020

Available Online:

10 August 2020
A B S T R A C T

The present study entitled "Evaluation of thirty amaranthus genotypes (Amaranthus tricolor L.) for different biometric characters" was carried out in the Department of Plant Breeding and Genetics, College of Agriculture, Vellayani during 2016-2018, with an objective to evaluate the amaranthus genotypes in terms of yield and other yield attributing characters and to assess the variability. The study was conducted with thirty genotypes and evaluated for thirteen characters. The genotype Madhur local (A22) recorded highest yield plant $^{-1}(125.926 \mathrm{~g})$ and least incidence of leaf blight. The genotypes showed varied responds towards different characters studied which concluded the presence of high variability exists in the germplasm of amaranthus, which could be exploited through selection and further breeding programme.

\section{Introduction}

Amaranthus (Amaranthus tricolor L.) is a popular leafy vegetable commonly consumed in Kerala. It is the important crop within Kerala farmers as sole crop or intercrop. Amaranthus belongs to the family Amaranthaceae, consists of diverse species as leafy amaranth, grain amaranth and ornamental amaranth. It is rich in terms of nutrients like protein, vitamin A, fibre content and ascorbic acid. Variability present in the collection of germplasm is pre requisite for crop improvement. Exploitation of variability present in the germplasm enhances the crop improvement. The amaranthus crop is variable in terms of colour, plant morphology, inflorescence pattern and crop duration. The plant breeder can exploit the existing variability from the amaranthus germplasm and can improve the objectives accordingly. The present study was aimed at identifying and evaluating the amaranthus genotypes for the variability and further exploitation through selection. 
Hamid et al., (1989) revealed that height and stem girth are positively correlated with yield in amaranthus, from the study of performance of some local and exotic germplasm of amaranthus. Twenty three amaranthus genotypes were evaluated and the variability in stem diameter was ranged from 0.30 to $0.40 \mathrm{~cm}$ with mean of $0.35 \mathrm{~cm}$. The genotype AMAR-23 recorded highest stem girth of 0.40 $\mathrm{cm}$ and AMAR- 04 showed the lowest of 0.30 $\mathrm{cm}$ in stem diameter (Jangde, 2016).

Variability in length of leaf lamina was observed by Celine et al., (2007) in a study of eighty nine accessions of amaranthus. The accessions Am 67 and Am 24 were had the maximum $(21.1 \mathrm{~cm})$ and the minimum $(7.4$ $\mathrm{cm})$ length of leaf lamina accordingly. The genotype $\mathrm{CO} 5$ had reported the maximum petiole length $(11 \mathrm{~cm})$, followed by A40 $(7.5$ $\mathrm{cm})$ and $\mathrm{CO} 4 \mathrm{had}$ minimum $(3.38 \mathrm{~cm})$ at 30 DAS (Selvaraj, 2004). Joshi et al., (2011) reported a wide range of variability in leaf width $(5.2$ to $12.7 \mathrm{~cm})$ indicated the possible exploitation of variation for amaranthus improvement.

Eight red amaranthus were studied by Mohideen et al., (1983) and revealed that types A. 144, A. 145 and local 1 were having tall growth habit and long duration with a few or no branches. Yield plant ${ }^{-1}$ in amaranthus varied from 1.18 to $3.29 \mathrm{~kg}$ with an average of $2.25 \mathrm{~kg}$ (Shukla and Singh, 2000). Shukla et al., (2004) reported that the amaranthus strain AV-41 showed highest foliage yield (5.99 $\mathrm{kg} \mathrm{plot}^{-1}$ ) and the heritability estimates were high for all the traits except number of branches plant $^{-1}$ and moisture content. Various workers reported the yield of amaranthus ranged from 4.0 to $16.5 \mathrm{t} \mathrm{ha}^{-1}$ (Campbell and Abbott, 1982) and from 9.90 to $18.30 \mathrm{t} \mathrm{ha}^{-1}$ (Makus, 1984). Among the nineteen Amaranthus spp. Sirohi and Sivakami (1995) reported PusaKirti (A. tricolor) and PusaKiran (A tricolor $\times A$. tristis) recorded high yield of 50 to $55 \mathrm{t} \mathrm{ha}^{-1}$ and $35 \mathrm{t} \mathrm{ha}^{-1}$ respectively. Priya (1998) conducted experiment in various genotypes of amaranthus and obtained the highest yield for Amt 193 (304.5 g plant $^{-1}$ ) and the genotype A 24 from A. tricolor showed the highest leaf to stem ratio of 1.57. Selvaraj (2004) revealed that optimum stage of harvest for yield and stem yield was between 30-40 DAS. Varalakshmi and Reddy (1994) studied 25 different lines of vegetable amaranthus and obtained mean values of $35.65 \mathrm{~cm}, 7.35 \mathrm{~cm}$ and $10.58 \mathrm{~cm}$ for plant height, leaf breadth and length respectively. Celine et al., (2007) screened eighty nine diverse accessions of amaranthus for resistance to leaf blight caused by Rhizoctonia solani. A. dubius and $A$. hypochondriacus were found free from incidence of leaf blight, A. tricolor showed varied levels of susceptibility.

Scoring was done on 0 to 4 scales from which the highest incidence was obtained in Am1 (2.6). Celine et al., (2011) observed that superior high yielding amaranthus accessions like AD-30, AD-23, and AD-22 were field resistant to leaf blight. Leaf webber (Hymenia recurvalis) was noticed as major pest in amaranthus (A.tricolor L.) field whereas red spider mite was found to be the minor pest (Muralikrishna, 2015).

\section{Materials and Methods}

Present study was conducted at Department of Plant Breeding and Genetics, College of Agriculture, Vellayani, with thirty genotypes of amaranthus evaluated in a Randomized Block Design (RBD) with three replications during 2016-2017. The amaranthus seedlings were transplanted to main field 21 DAS with a spacing of $30 \times 20 \mathrm{~cm}$. A total of twenty plants were maintained in each plot, each genotype was considered as each treatment. The observations on biometric characters were taken 30 days after transplanting. The main observations were taken on following characters, 


\section{Stem girth $(\mathbf{c m})$}

The main stem girth at the collar region was taken by using a twine. Mean girth was measured and expressed in centimetres.

\section{Length of leaf lamina $(\mathrm{cm})$}

Length was recorded from the fifth leaf from top of the selected plants. Mean length was measured and expressed in centimetres.

\section{Petiole length $(\mathrm{cm})$}

The petiole length of the same plant which was used for recording length was measured and the mean expressed in centimetres.

\section{Leaf width $(\mathrm{cm})$}

The width of the same leaf of the plant which was used for recording length was measured and the mean expressed in centimetres.

\section{Internodal Length (cm)}

Internodal length of the same leaf of the plant which was used for recording length was measured and the mean expressed in centimetres.

\section{Number of branches}

The total branches of the each observational plant were counted and average was worked out.

\section{Yield plant ${ }^{-1}(g)$}

Three cuttings were taken from each plant. The first cutting was taken at 30 days after transplanting and the subsequent two cuttings were taken at intervals of two weeks. The yield obtained cutting ${ }^{-1}$ was recorded and expressed in grams plant ${ }^{-1}$.

\section{Yield $\operatorname{plot}^{-1}(\mathbf{k g})$}

Yield from the twenty plants were taken for each cuttings, total yield was expressed in kilogram plot $^{-1}$.

\section{Leaf to stem ratio}

Leaf to stem ratio was taken by dividing the weight of leaves with weight of stem. The leaf to stem ratio was worked out for the total of three cuttings.

\section{Days to $50 \%$ bolting}

Days to $50 \%$ bolting was recorded from the plants left unharvested.

\section{Plant height (cm)}

Plant height was recorded from each observational plant by measuring the length of main stem from ground level to the top leaf bud of plants. Mean length was measured and expressed in centimetres.

\section{Incidence of leaf blight}

The genotypes were monitored for the incidence and intensity of leaf blight and scoring was done on a 0-4 scale (Celine et al., 2013).

0 - No incidence

1- Up to $25 \%$ leaf area infected

2- Up to $50 \%$ leaf area infected

3- Up to $75 \%$ leaf area infected

4- Up to $100 \%$ leaf area infected

Scoring was done at biweekly intervals after transplanting and average score worked out.

\section{Incidence of leaf webber}

Incidence and intensity of leaf webber attack was observed and scored by using the following score chart (Sathy, 2006) 
0 - No incidence

1- Mild (25\%)

2- Medium (50\%)

3- Severe $(75 \%)$

4- Very severe $(100 \%)$

Scoring was done three times at fortnightly intervals after transplanting and average score was recorded.

\section{Results and Discussion}

Thirty genotypes of amaranthus were evaluated, performance of each genotype shown significant difference for the characters under study. The results are presented in the table 1 .

Stem girth was noticed to be the maximum for the genotype A9 $(3.745 \mathrm{~cm}$. The minimum stem girth was noticed for the genotype A25 $(1.759 \mathrm{~cm})$ Length of leaf lamina varied from $12.780 \mathrm{~cm}$ to $8.687 \mathrm{~cm}$. The maximum was observed for A28 genotype $(12.870 \mathrm{~cm})$. The minimum length of leaf lamina was observed for the genotype A26 $(8.687 \mathrm{~cm})$. The maximum petiole length was observed for the genotype A9 $(5.175 \mathrm{~cm})$, the least petiole length was noticed for the genotype A11 $(2.873 \mathrm{~cm})$.

The genotype A9 registered highest leaf width $(8.268 \mathrm{~cm})$. The internodal length ranged from $4.640 \mathrm{~cm}$ (A21) to $1.643 \mathrm{~cm}$ (A14). The number of branches ranged from 11.467 (genotype A21) to 0.000 (genotype A7 and A15).

The genotype A22 registered high yield plant ${ }^{1}(125.926 \mathrm{~g})$ and high yield $\operatorname{plot}^{-1}(2.513 \mathrm{~kg})$ and the lowest yield plant ${ }^{-1}$ was reported for the genotype A18 (64.163 g) with $1.436 \mathrm{~kg}$ (lowest) yield plot ${ }^{-1}$. Significant variation was observed for the character leaf to stem ratio. It was ranged from 1.678 (A15) to 0.491 (A7). Days to $50 \%$ bolting was found to be highest for the genotype A21 (49.667) and the lowest for the genotype A16 (30. 667). The maximum plant height was recorded for the genotype A7 $(72.500 \mathrm{~cm})$. The minimum plant height was recorded for the genotype A16 $(17.840 \mathrm{~cm})$.

Incidence of leaf blight was scored according to 0-4 scale, the highest score was reported for the genotype A6 (1.990) and the lowest score 0 were reported for the genotypes A1, A2, A8, A11, A13, A15, A21, A22, A24, A26, A27 and A28.

Scoring for the incidence leaf webber were done with 0-4 scale, maximum score was recorded for the genotype A17 (3.260) which was on par with A14 (3.080). The score 0 was reported for genotypes A9, A20, A21, A23 and A26.

A wide range of observations were reported for different genotypes in terms of biometric characters which indicate the extent of variability present in the germplasm. In the present study, under first experiment thirteen biometric characters were studied for thirty genotypes and all the characters showed considerable variation among the genotypes evaluated.

Analysis of variance showed significant differences for all the 13 traits of 30 genotypes indicating the significant variability for all the characters of amaranthus under study which could be exploited through selection. Similar results were noticed in amaranthus by Selvaraj (2004), Shukla et al., (2005), Pan et al., (2008), Diwan (2015) and Jangde (2016) (Table 2). 
Table.1 List of Amaranthus (Amaranthus tricolor L.) genotypes used in the study

\begin{tabular}{|c|c|c|}
\hline Genotypes No. & Name of the genotypes & Sources \\
\hline A1 & Elamad local & Kollam district \\
\hline A2 & Palakkadu local & Palakkad district \\
\hline A3 & Ayira local & Thiruvananthapuram district \\
\hline A4 & Kalliyoor local & Thiruvananthapuram district \\
\hline A5 & Thrissur local & Thrissur district \\
\hline A6 & Anachal local & Idukki district \\
\hline A7 & Haripad local & Alappuzha district \\
\hline A8 & Manacaud local & Thiruvananthapuram district \\
\hline A9 & Kazhakkuttom local & Thiruvananthapuram district \\
\hline A10 & Kannur local & Kannur district \\
\hline A11 & Chettikulangara local & Alappuzha district \\
\hline A12 & Kottembram local & Kozhikode district \\
\hline A13 & Thiruthi local & Kozhikode district \\
\hline A14 & Adoor local & Pathanamthitta district \\
\hline A15 & Karnataka local & Kasaragode district \\
\hline A16 & Kollamcode local & Kanyakumari district \\
\hline A17 & Trivandrum local & Thiruvananthapuram district \\
\hline A18 & Kumily local & Idukki district \\
\hline A19 & Nilamel local & Kollam district \\
\hline A20 & Poonkulam local & Thiruvananthapuram district \\
\hline A21 & Aryanadu local & Thiruvananthapuram district \\
\hline A22 & Madhur local & Kasaragod district \\
\hline $\mathbf{A 2 3}$ & Alathur local & Palakkad district \\
\hline A24 & Maranalloor local & Thiruvananthapuram district \\
\hline $\mathbf{A 2 5}$ & Nellad local & Ernakulam district \\
\hline A26 & Aleppy local & Alappuzha district \\
\hline A27 & Cherthala local & Alappuzha district \\
\hline A28 & Ayyanthole local & Thrissur district \\
\hline A29 & Kannara local & Thrissur district \\
\hline A30 & Kilimanur local & Thiruvananthapuram district \\
\hline
\end{tabular}


Table.2 Mean performance of 13 biometric characters of 30 genotypes of Amaranthus under field condition

\begin{tabular}{|c|c|c|c|c|c|c|c|c|c|c|c|c|c|c|}
\hline SI No. & Genotypes & $\mathbf{X} 1$ & $\mathrm{X} 2$ & $\mathbf{X 3}$ & X 4 & X5 & $\times 6$ & $\mathbf{X} 7$ & $\times 8$ & X9 & X 10 & X 11 & X 12 & X13 \\
\hline 1 & A1 & 2.880 & 12.291 & 4.472 & 7.930 & 2.642 & 7.033 & 86.680 & 1.730 & 0.951 & 35.333 & 32.187 & 0.000 & 2.170 \\
\hline 2 & A2 & 2.657 & 12.098 & 4.353 & 7.778 & 2.673 & 6.400 & 109.26 & 2.295 & 1.577 & 31.333 & 30.780 & 0.000 & 0.320 \\
\hline 3 & A3 & 2.700 & 10.325 & 3.347 & 6.283 & 3.183 & 6.817 & 87.323 & 1.746 & 1.249 & 43.333 & 30.033 & 1.716 & 0.730 \\
\hline 4 & A4 & 3.200 & 9.1800 & 3.027 & 5.653 & 3.850 & 9.667 & 125.22 & 2.153 & 0.707 & 47.000 & 39.867 & 0.830 & 0.473 \\
\hline 5 & A5 & 3.037 & 10.692 & 3.683 & 6.358 & 3.633 & 9.283 & 82.837 & 1.656 & 0.906 & 39.000 & 33.890 & 1.246 & 2.073 \\
\hline 6 & A6 & 3.288 & 11.580 & 3.493 & 6.768 & 2.957 & 8.733 & 108.27 & 2.154 & 0.713 & 43.667 & 34.520 & 1.990 & 0.356 \\
\hline 7 & A7 & 3.033 & 11.000 & 3.700 & 6.320 & 4.267 & 0.000 & 114.42 & 2.278 & 0.491 & 48.333 & 72.500 & 0.846 & 0.340 \\
\hline 8 & A8 & 2.977 & 10.650 & 3.773 & 5.307 & 2.358 & 7.520 & 83.690 & 1.655 & 0.719 & 39.000 & 32.370 & 0.000 & 2.860 \\
\hline 9 & A9 & 2.893 & 12.445 & 5.175 & 8.268 & 2.733 & 6.933 & 97.696 & 1.962 & 1.428 & 39.667 & 33.675 & 0.283 & 0.000 \\
\hline 10 & A10 & 3.745 & 12.767 & 3.717 & 8.265 & 4.080 & 8.267 & 97.993 & 1.943 & 0.916 & 31.667 & 35.750 & 0.603 & 2.393 \\
\hline 11 & A11 & 2.953 & 9.9800 & 2.873 & 6.668 & 3.927 & 9.333 & 74.466 & 1.486 & 0.660 & 48.000 & 33.833 & 0.000 & 1.373 \\
\hline 12 & A12 & 3.113 & 10.690 & 3.333 & 6.767 & 2.767 & 8.867 & 95.185 & 1.903 & 0.857 & 44.000 & 40.580 & 0.770 & 1.956 \\
\hline 13 & A13 & 3.327 & 10.713 & 3.733 & 6.380 & 4.133 & 8.467 & 74.387 & 1.486 & 0.691 & 38.000 & 44.900 & 0.000 & 0.660 \\
\hline 14 & A14 & 1.780 & 10.653 & 3.433 & 6.433 & 1.643 & 6.933 & 71.873 & 1.437 & 1.224 & 36.000 & 31.087 & 0.280 & 3.080 \\
\hline 15 & A 15 & 2.075 & 10.873 & 3.320 & 6.107 & 3.213 & 0.000 & 74.823 & 1.496 & 1.678 & 48.667 & 35.100 & 0.000 & 2.496 \\
\hline
\end{tabular}

X1- Stem girth , X2- Length of leaf lamina, X3- Petiole length, X4- Leaf width, X5- Internodal length, X6- Number of branches, X7- Yield plant ${ }^{-1}$, X8- Yield plot $^{-1}$, X9- Leaf to stem ratio, X10- Days to 50\% bolting, X11- Plant height, X12- Incidence of leaf blight, X13- Incidence of leaf webber. 
Table.2 Continued

\begin{tabular}{|c|c|c|c|c|c|c|c|c|c|c|c|c|c|c|}
\hline SI No. & Genotypes & $\mathbf{X} 1$ & $\mathrm{X} 2$ & $\mathbf{X 3}$ & X 4 & X5 & X 6 & $\times 7$ & $\times 8$ & X9 & X 10 & X 11 & X 12 & X13 \\
\hline 16 & A16 & 2.623 & 11.453 & 3.540 & 7.007 & 3.407 & 7.267 & 83.736 & 1.676 & 1.232 & 30.667 & 17.840 & 0.323 & 2.286 \\
\hline 17 & A17 & 2.900 & 10.653 & 2.927 & 6.480 & 2.380 & 8.533 & 71.796 & 1.436 & 1.281 & 48.333 & 32.113 & 0.630 & 3.260 \\
\hline 18 & A18 & 2.567 & 9.9000 & 3.100 & 6.133 & 2.617 & 8.400 & 64.163 & 1.466 & 0.724 & 47.667 & 33.867 & 0.556 & 2.923 \\
\hline 19 & A19 & 3.347 & 10.400 & 3.200 & 5.820 & 3.947 & 7.600 & 87.893 & 1.753 & 0.942 & 46.667 & 40.900 & 1.143 & 0.576 \\
\hline 20 & A20 & 2.707 & 11.747 & 3.813 & 7.587 & 3.000 & 6.600 & 103.09 & 2.063 & 1.530 & 35.000 & 35.300 & 0.890 & 0.000 \\
\hline 21 & A21 & 3.387 & 8.7230 & 3.000 & 5.350 & 4.640 & 11.46 & 106.71 & 2.136 & 0.955 & 49.667 & 40.167 & 0.000 & 0.000 \\
\hline 22 & A22 & 2.633 & 9.9700 & 3.007 & 5.627 & 2.513 & 9.667 & 125.92 & 2.513 & 0.620 & 48.000 & 33.033 & 0.000 & 0.253 \\
\hline 23 & A23 & 3.537 & 10.287 & 3.920 & 6.360 & 3.507 & 9.267 & 96.226 & 1.924 & 0.898 & 42.000 & 32.053 & 1.280 & 0.000 \\
\hline 24 & A24 & 3.395 & 10.853 & 4.447 & 6.590 & 3.280 & 7.600 & 82.826 & 1.656 & 1.012 & 42.000 & 34.453 & 0.000 & 2.720 \\
\hline 25 & A25 & 1.759 & 10.965 & 3.712 & 6.505 & 2.167 & 8.350 & 76.233 & 1.523 & 0.846 & 34.000 & 28.545 & 0.250 & 1.800 \\
\hline 26 & A26 & 2.487 & 8.6870 & 3.330 & 6.460 & 2.227 & 9.267 & 75.090 & 1.503 & 1.277 & 35.000 & 25.803 & 0.000 & 0.000 \\
\hline 27 & A27 & 2.980 & 8.9130 & 3.933 & 5.800 & 2.667 & 8.467 & 94.183 & 1.883 & 0.804 & 43.000 & 34.200 & 0.000 & 1.220 \\
\hline 28 & A28 & 3.037 & 12.780 & 4.373 & 6.813 & 2.820 & 8.200 & 116.98 & 2.339 & 0.607 & 40.000 & 34.133 & 0.000 & 1.720 \\
\hline 29 & A29 & 2.940 & 9.4670 & 3.387 & 5.653 & 3.003 & 8.733 & 97.923 & 1.956 & 0.852 & 42.333 & 40.133 & 1.170 & 0.726 \\
\hline \multirow[t]{3}{*}{30} & A30 & 3.262 & 10.313 & 3.158 & 6.770 & 2.600 & 9.133 & 96.666 & 1.936 & 1.086 & 42.000 & 35.413 & 1.503 & 1.263 \\
\hline & S.E & 0.379 & 0.496 & 0.469 & 0.489 & 0.400 & 0.716 & 6.312 & 0.025 & 0.100 & 0.894 & 2.818 & 0.258 & 0.112 \\
\hline & $\mathrm{CD}(\mathbf{0 . 0 5})$ & 0.760 & 0.994 & 0.940 & 0.981 & 0.803 & 1.433 & 12.638 & 0.143 & 0.227 & 2.345 & 5.643 & 0.122 & 0.201 \\
\hline
\end{tabular}

X1- Stem girth, X2- Length of leaf lamina, X3- Petiole length, X4- Leaf width, X5- Internodal length, X6- Number of branches, X7- Yield plant ${ }^{-1}$, X8- Yield plot $^{-1}$, X9- Leaf to stem ratio, X10- Days to $50 \%$ bolting, X11- Plant height, X12- Incidence of leaf blight, X13- Incidence of leaf webber. 


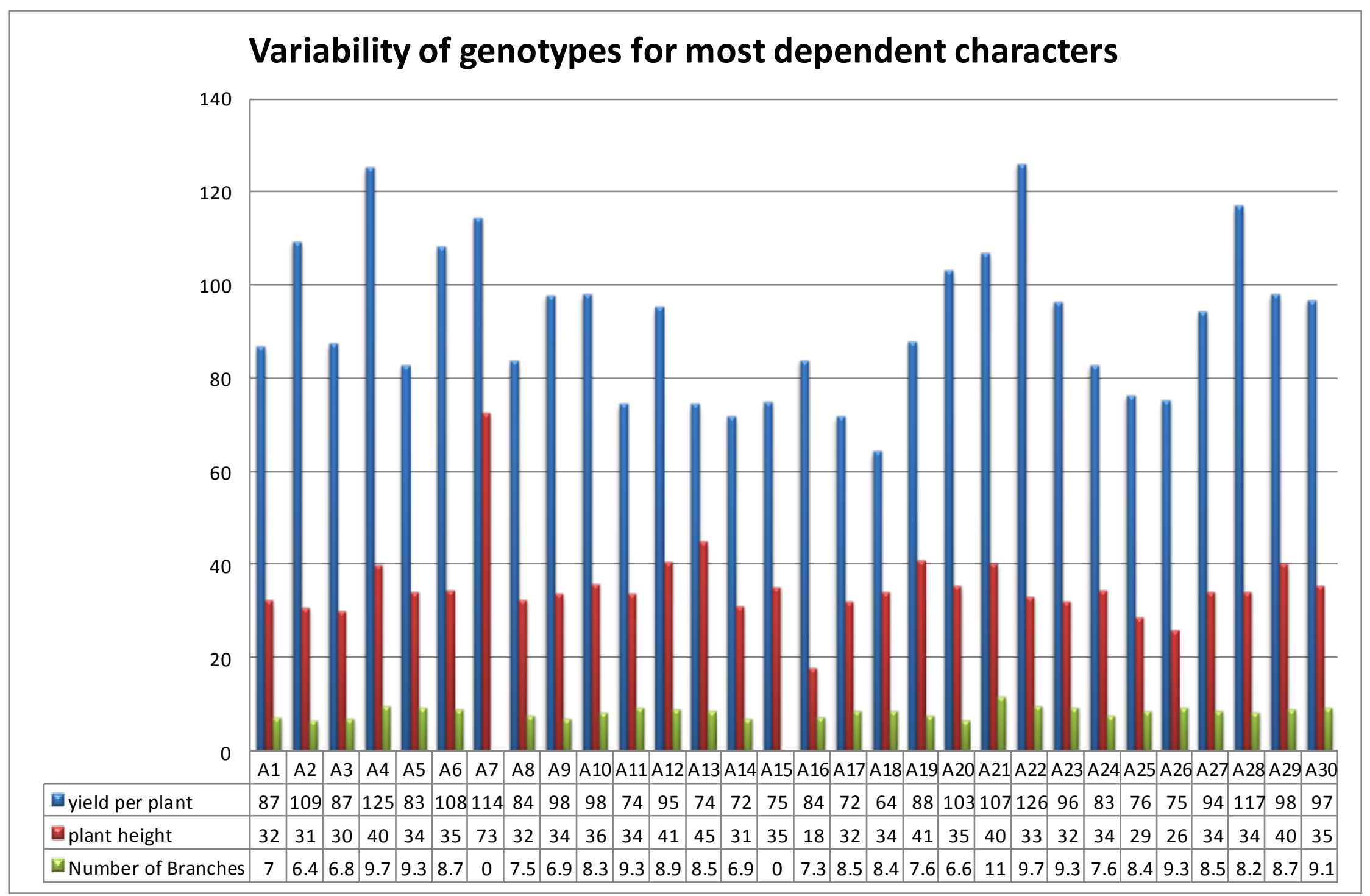


Plate.1 High yielding selected amaranthus genotypes (A) Madhur local, (B) Kalliyoor local, (C) Ayyanthole local and (D) Palakkadu local

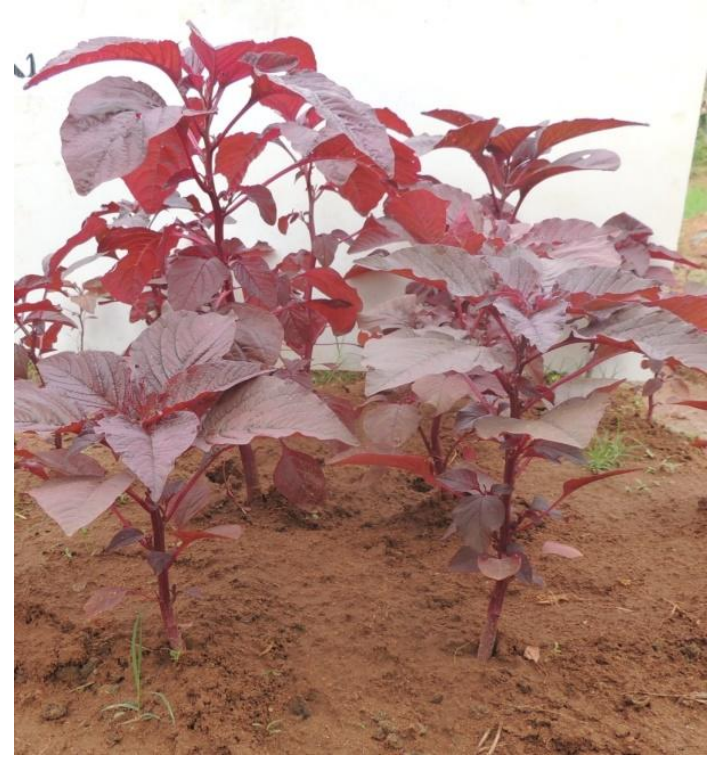

(A) MADHUR LOCAL

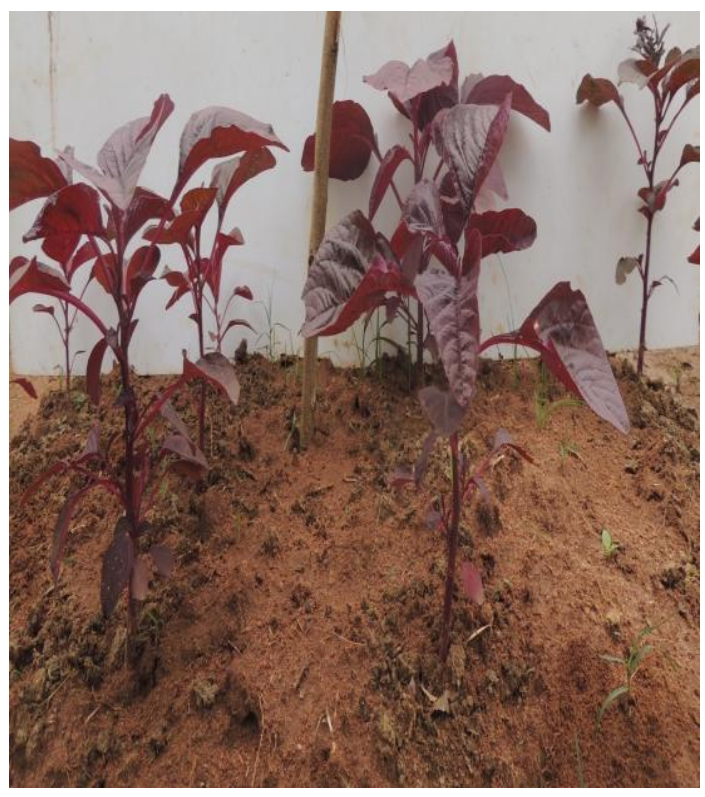

(C) AYYANTHOLE LOCAL

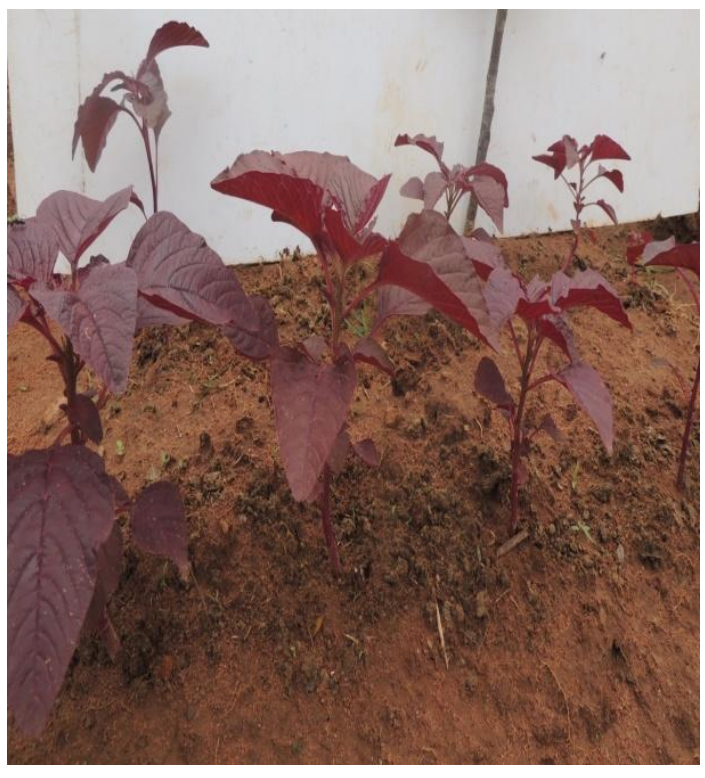

(B) KALLIYOOR LOCAL

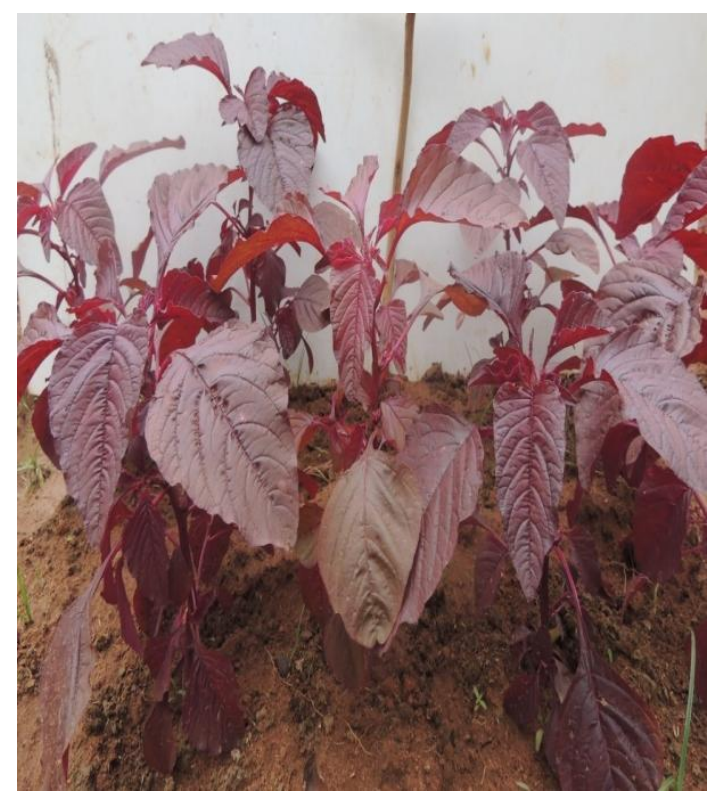

(D) PALAKKADU LOCAL 
High amount of variability in amaranthus was recorded for the characters like plant height, yield per plant and weight of stem and leaves were in accordance with results of Panda et al., (2017). High amount of heritability also noticed for the traits length of leaf lamina, plant height and yield per plant.

Contribution of different traits in amaranthus for the crop improvement was proven by Gerrano et al., (2015), Praveen et al., (2014) and Kumar et al., (2018), which indicates that, the characters are taken in this study, can be considered as main yield contributing traits in amaranthus.

The greatest variability was recorded for yield plant $^{-1}$ which could be used as selection criteria for crop improvement in Amaranthus tricolor L. Supporting evidences were given by Shuklaet al., (2005) and Celine et al., (2007) in amaranthus.

The highest range of variation was recorded for number of branches, length of leaf lamina, yield plant $^{-1}$, days to $50 \%$ bolting, plant height, incidence of leaf webber in amaranthus. Supporting evidences were given by Sathy (2006) and Celine et al., (2007) in amaranthus.

The genotype A22 (Madhur local) recorded the highest yield plant $^{-1}$ followed by A4 (Klliyoor local), A28 (Ayyanthole local), A7 (Haripad local), A2 (Palakkadu local), A6 (Anachal local), A21 (Aryanadu local), A20 (Poonkulam local) A9 (Kazhakkuttom local) and A29 (Kannara local).

In conclusion, the present study was conducted to evaluate the variability present in the thirty amaranthus genotypes. Amaranthus tricolor L. showed tremendous variation in terms of different biometric characters including yield, which depicts the probability in amaranthus improvement in the field of breeding through exploitation of variability and further improvement. The amaranthus genotype Madhur local was identified as the best genotype under field condition, this genotype can be further screened for better genetic exploitation.

\section{Acknowledgement}

We would like to express our heartfelt thanks to Dept. of Plant Breeding and Genetics, College of Agriculture, Vellayani for providing facilities to conduct the study successfully.

\section{References}

Campbell, T.A. and Abbott, J.A. 1982. Field evaluation of vegetable amaranth (Amaranthus spp.).Hort. Sci. 17:407-409.

Celine, V.A., Shankaran, S.S., Seema, S., Deepa, S.N., Sreelathakumary, I., and Vahab, A.M. 2007. Characterization and evaluation of vegetable amaranthus (Amaranthus tricolor L.) for high yield, quality and resistance to Rhizoctonia solani. ISHS ActaHortic. 752: 81.

Celine, V.A., Sindhu, L., and Rajamony, L. 2011. Evaluation of vegetable amaranthus (Amaranthus dubius Mart. Ex Thell.), Indian J. Hort.68 (1): 131-135.

Diwan, I.S. 2015.Genetic variability in amaranthus (Amaranthus sp.) germplasm. M.Sc.(Ag) thesis, college of agriculture, Indira Gandhi Krishi Vishwavidyalaya, Raipur, 81p.

Gerrano, S.A., Jansen van Rensburg and Adebola, O.P. 2015.Genetic diversity of Amaranthus species in South Africa. South Afr. J. Plant Soil, 32(1): 39-46

Hamid, M.M., Ahmed, N.U., and Hossain, S.M.M. 1989. Performance of some local and exotic germplasm of amaranth. Argic. Sci. Digest 9:202-204.

Jangde, B. 2016. Variability and association studies for foliage yield components and its quality parameters in vegetable amaranthus (Amaranthus tricolor L.). M.Sc. (Hort) thesis, Indira Gandhi Krishi 
Vishwavidyalaya, Raipur, Chhattisgarh, $123 p$.

Joshi, V., Vijaya, M., Sireesha, K., and Latha, P. M. 2011.Characterization and preliminary evaluation of vegetable amaranth (Amaranthus spp.).Veg. Sci. 38(2):239-240.

Kumar, Y., Prasad, R. and Singh, R.P. 2018. Studies on Collection and Evaluation of Genetic Variability Available in Amaranthus (Amaranthus spp.) under Chhattisgarh Plain Condition. Int. J. Curr. Microbiol. Appl. Sci. 7(11): 3540-3547.

Makus, D.J. 1984. Evaluation of amaranth as a potential green crop in the mid-south.Hort. Sci. 19: 881-883.

Mohideen, K.M., Muthukrishnan, C.R., Shanmugavelu, K.G., Rengaswami, P., and Vadivel, E. 1983.Evaluation of grain amaranth type at Coimbatore.S. Indian Hortic. 31:11-14.

Panda, R.K., Mishra, S.P., Nandi, A., Sarkar, S., Pradhan, K., Das, S., Patnaik, A and Padhiary, A.K. 2017. Genetic variability and varietal performance in vegetable amaranthus (Amaranthus sp.). $J$. Pharmacognosy Phytochem. 6(6):12501256.

Parveen, M., Chattopadhyay. N.C and Tah, J. 2014. Strategy of biometric evaluation of vegetative yield attributes of Amaranth cultivars. Biosci. Discovery, 5(1): 70-73

Selvaraj, D.G. 2004. Variability studies in amaranthus. M.Sc. (Hort.) Thesis, Tamil Nadu Agricultural University, 119p.

Shukla, S. and Singh, S.P. 2000. Studies on genetic parameters in vegetable amaranth. $J$. Genet. 54: 133-135.

Shukla, S., Bhargava, A., Chatterjee, A., and Singh, S. P. 2004. Estimates of genetic parameters to determine variability for foliage yield and its different quantitative and qualitative traits in vegetable amaranth (A. tricolor).J. Genet. Plant Breed.58(2): 169-176.

Sirohi, P.S. and Sivakami, N. 1995.Vegetable amaranth varieties from Indian Agricultural Research Institute. Indian Hort. 40: 17-20.

Priya, V.P. 1998. Screening amaranth genotypes (Amaranthus spp.) for yield, quality and resistance to biotic stress.M.Sc. (Hort) thesis, Kerala Agricultural University, Thrissur, 103p.

Selvaraj, D.G. 2004. Variability studies in amaranthus. M.Sc. (Hort.) Thesis, Tamil Nadu Agricultural University, 119p.

Varalakshmi, B. and Reddy, P.V.V. 1994. Variability, heritability and correlation studies in vegetable amaranthus. $S$. Indian Hortic. 42:361-364.

Muralikrishna, P. 2015. Management of pest and pesticide residue in vegetable amaranthus (Amaranthus tricolor L.).Msc. (Agri.), Kerala Agricultural University, Thrissur, $216 \mathrm{p}$.

Shukla, S., Bhargava, A., Chatterjee, A., Srivatsava, A., and Singh, S.P. 2005.Estimates of genetic variability in vegetable amaranth (Amaranthus tricolor) over different cuttings. Hort. Sci. 32(2):6067.

Pan, R.S., Singh, A.K., Kumar, S., and Rai, M. 2008.Genetic variation and character association in vegetable amaranth (Amaranthus tricolor L.).Veg. Sci. 35(1): 8183.

Sathy, S.S. 2006. Characterization and evaluation of landraces of Amaranthus (Amaranthus spp.). M.Sc. (Ag) thesis, Kerala Agricultural University, Thrissur, 113p.

\section{How to cite this article:}

Shahiba A. M, Beena Thomas and Arun Chacko. 2020. Evaluation of Thirty Amaranthus Genotypes (Amaranthus tricolor L.) for Different Biometric Characters. Int.J.Curr.Microbiol.App.Sci. 9(08): 1621-1631. doi: https://doi.org/10.20546/ijcmas.2020.908.186 